\title{
ANALISIS NIAT PEMBELIAN ULANG E-COMMERCE MOBILE DENGAN PENDEKATAN TECHNOLOGY ACCEPTANCE MODEL (TAM)
}

\author{
REPURCHASE INTENTION ANALYSIS OF MOBILE E-COMMERCE USING \\ TECHNOLOGY ACCEPTANCE MODEL (TAM) APPROACH
}

\author{
Widarto Rachbini")1, Fahruddin Salim*), Marissa Grace Haque ${ }^{* *}$, dan Emi Rahmawati***) \\ *) Universitas Pancasila \\ Jl.Srengseng Sawah, Jagakarsa Jakarta Selatan 12640 \\ ${ }^{* *}$ Indonesia Banking School \\ Jl. Kemang Raya No.35, Jakarta Selatan 12730 \\ ***) Universitas Trunojoyo \\ Jl. Raya Telang Kamal, Bangkalan 69162
}

\begin{abstract}
This research aims to test several antecedents as trust, risk, credibility, internet use, and those impact on intention for online transactions via e-commerce mobile platform and Technology Acceptance Model. The research integrated the Technology Acceptance Model (TAM) with four main constructs, namely internet use, trust, credibility, and risk, which is very important to predict individual acceptance of online transactions. Research methods were using structural equation model analysis (SEM), path analysis, and confirmatory factor analysis (CFA) of AMOS 24.0 to examine all the hypotheses, reliability, and validity for each indicator or measuring instrument. The research findings show that credibility and trust played an important role in online transaction acceptance in the e-commerce industry. Furthermore, the findings consistently supported previous studies of TAM where perceived ease of use and perceived usefulness played a role in both directly and indirectly on repurchase intention of mobile e-commerce platform. This study implied that e-commerce players must pay attention to simplifying the customer journey. Another implication was to communicate the credibility and trust aspects to the consumers. Thus the customers could understand and could be convinced that mobile e-commerce platforms are credible shopping market.
\end{abstract}

Keywords: technology acceptance model, electronic transaction, intention, credibility, trust

\begin{abstract}
Abstrak: Penelitian ini bertujuan menguji beberapa anteseden seperti kepercayaan, resiko, kredibilitas, internet use, dan pengaruhnya terhadap niat bertransaksi ulang secara online dalam e-commerce mobile platform dengan pengujian melalui model penerimaan teknologi. Penelitian ini mencoba mengintegrasikan model penerimaan teknologi (Technology Acceptance Model (TAM) dengan empat konstruk, yaitu internet use, kepercayaan, kredibilitas, dan risiko yang diduga sangat penting dalam memprediksi penerimaan individu atas transaksi online. Metode penelitian menggunakan teknik analisis structural equation model (SEM) dan analisa jalur serta confirmatory factor analysis (CFA) melalui AMOS 24.0 untuk menguji hipotesis, reliabilitas, dan validitas masing-masing indikator atau alat ukur yang digunakan. Temuan dalam penelitian ini menunjukkan bahwa kepercayaan dan kredibilitas memainkan peran penting dalam penerimaan transaksi online pada industri e-commerce. Selain itu, hasil penelitian ini konsisten mendukung beberapa penelitian terdahulu terkait dengan TAM di mana kemudahan penggunaan (perceived ease of use) dan kegunaan (perceived usefulness) berperan baik secara langsung maupun tidak langsung terhadap niat pembelian ulang pada e-commerce mobile platform. Penelitian ini pun tentunya memiliki sejumlah implikasi manajerial di mana para praktisi e-commerce harus memberikan perhatian lebih pada penyederhanaan customer journey dan mampu mengkomunikasikan aspek kredibilitas dan kepercayaan dengan baik ke consumer market agar mampu dipahami dan dapat meyakinkan konsumen atau pelanggan bahwa e-commerce mobile platform merupakan tempat berbelanja yang kredibel (dapat dipercaya).
\end{abstract}

Kata kunci: model penerimaan teknologi, transaksi elektronik, niat beli, kredibilitas, kepercayaan

\footnotetext{
${ }^{1}$ Corresponding author:

Email: widarto@univpancasila.ac.id
} 


\section{PENDAHULUAN}

Dengan kemajuan pesat dalam teknologi informasi dan komunikasi, robotika dan studi terkait dianggap sebagai salah satu faktor paling potensial yang mampu mengubah kehidupan manusia dan budaya (Park, 2016). Total jumlah pengguna internet di dunia telah mencapai lebih dari 4,1 miliar users dimana Asia merupakan benua dengan jumlah pengguna terbanyak, yakni sebanyak lebih dari 2 miliar pengguna internet. Bila melihat populasi dan pengguna internet yang sangat besar di benua Asia, Indonesia dengan jumlah penduduk sebesar 266 juta menjadi salah satu negara yang memberikan kontribusi besar terkait hal ini, karena pengguna internet di Indonesia pada Desember 2017 mencapai angka lebih dari 143 juta (Internetworldstats, 2018). Selanjutnya, berdasarkan salah satu laporan lembaga riset independen di Indonesia tercatat bahwa terdapat 265,4 juta total populasi Indonesia dengan 132,7 juta penduduk tersebut ialah pengguna aktif internet, serta sebesar 130 juta merupakan pengguna media sosial di tahun 2018 (Hootsuite, 2018).

Berkaitan dengan trend positif dan perkembangan dunia digital di dunia dan di Indonesia, dalam beberapa tahun terakhir, perkembangan infrastruktur internet terus berkembang dan inovasi dalam transaksi elektronik mendorong penerimaannya semakin meluas. Laju perkembangan teknologi informasi dan komunikasi (TIK) juga mendorong kemajuan ekonomi. Di era saat ini, dimana media sosial sangat populer di masyarakat, hubungan sosial di antara konsumen mendorong mereka berpartisipasi dalam aktivitas online, termasuk aktivitas perdagangan (Rachbini, 2017). Kemajuan pesat teknologi informasi dan komunikasi (TIK) dalam beberapa tahun terakhir telah sangat mengubah cara informasi diakses, disimpan, dan disebarluaskan (Weerasinghe dan Hindagolla, 2018).

Perkembangan ini memberikan gambaran yang lebih komprehensif, dan berguna bagi akademisi dan praktisi dalam membantu memahami perilaku transaksi online individu dalam e-commerce. Dalam penelitian ini, dasar teorotis dikembangkan melalui model penerimaan teknologi (Technology Acceptance Model/ TAM). TAM kurang umum daripada Theory Reasoned Action (TRA) untuk menentukan perilaku penggunaan teknologi hal ini dikarenakan TAM telah diterapkan dalam penelitian sistem informasi selama lebih dari dua dekade, maka sangat sesuai untuk mempelajari niat pengguna untuk menggunakan teknologi seluler (Andoh, 2018). Langkah penting dalam penelitan ini adalah mengembangkan dasar teoritis dan secara empiris memvalidasi model penerimaan teknologi (TAM) melalui penelitian dengan memprediksi penerimaan transaksi elektronik secara individu. Nilai TAM dalam konteks berbasis teknologi sangat penting (Bernadette, 1996; Venkatesh dan Davis, 2000; Gefen dan Straub, 2002; Pavlou, 2003). Oleh karena itu, menggunakannya dalam konteks transaksi elektronik berbasis teknologi adalah sangat rasional. Demikian pula, dengan menggunakan kepercayaan, kredibilitas dan persepsi risiko dalam konteks transaksi elektronik, khususnya pada e-commerce mobile platform.

Stewart et al. (2002) dan Aladwani, (2003) berpendapat bahwa pengertian kepercayaan merupakan komponen terpenting dari transaksi konsumen-pemasar. Oleh karena itu, persepsi kepercayaan, kredibilitas dan risiko cenderung menjadi faktor penting dalam memprediksi penerimaan transaksi elektronik secara individual. Penelitian ini bertujuan untuk secara empiris menyelidiki beberapa anteseden seperti kepercayaan, risiko, dan kredibilitas, serta pengaruhnya terhadap niat bertransaksi secara online dengan menguji model penerimaan teknologi. Selain itu, penelitian ini berupaya memperkaya atau mengembangkan TAM di mana studi-studi terdahulu hanya berfokus seperti pada penerimaan model teknologi online social network site (Ngiam dan Chaiyasoonthorn, 2011), e-learning (Correa et al. 2015), information communication technology (Salman et al. 2014), internet banking (Danurdoro, 2016), penggunaan Instagram untuk pembelian online (Indrayana et al. 2016), dan 3D food printing (Groot, 2018). Penelitian ini berupaya mengembangkan dan menambahkan konstruk internet use sebagai determinan perceived usefulness dan perceived ease of use dalam konteks e-commerce berbasis mobile platform di Indonesia serta pengaruh single construct lain seperti credibility, trust, dan risk yang juga berperan terhadap pengembangan TAM. Hal ini dapat dikatakan sebagai pengembangan dari sejumlah studiterdahulu, khususnya penelitian yang dilakukan oleh Holden et al. (2016) yang juga telah mengaplikasikan konsep perceived ease of use, usefulness dalam konteks health IT. Di sisi lain, penelitian ini juga cenderung hanya berfokus pada aspek fundamental (TRA) sebagai landasan untuk pengembangan pada penelitian-penelitian selanjutnya. 


\section{METODE PENELITIAN}

Data diperoleh melalui penyebaran kuesioner. Untuk memperoleh responden sesuai dengan kriteria yang telah ditetapkan oleh peneliti, maka identifikasi latar belakang demografis responden dilakukan. Penelitian ini berfokus pada responden yang pernah menggunakan atau bertransaksi via e-commerce mobile platform lebih dari satu kali. Metode pengambilan sampel dilakukan dengan metode purposive sampling (judgmental). Kriteria utama pemilihan sampel di dalam penelitian ini adalah pengguna internet yang sudah pernah melakukan transaksi secara elektronik di DKI Jakarta, melalui mobile platform.

Ukuran sampel dalam penelitian adalah 5-10 kali jumlah variable manifest (indikator) dari keseluruhan variabel laten. Dalam penelitian ini, jumlah indikator penelitian sebanyak 24 sehingga jumlah sampel minimum adalah 5 kali jumlah indikator atau sebanyak 5 × $24=120$ dan sampel maksimum adalah sebesar 240 .

Proses penelitian dilakukan pada bulan Februari sampai dengan Maret 2018 dengan responden yang merupakan penggunainternetdiDKIJakartayang pernahmelakukan transaksi elektronik (via mobile platform) serta para responden pernah melakukan transaksi elektronik lebih dari satu kali. Printed-questionaire berhasil disebarkan kepada 174 responden di DKI Jakarta dengan tingkat pengembalian jawaban kuesioner yang terisi lengkap dan sesuai kriteria, yakni sebanyak 150 . Dengan demikian, response rate penyebaran kuesioner adalah sebesar $86,21 \%$. Selanjutnya, metode analisis yang digunakan adalah Structural Equation Modeling (SEM) yang merupakan suatu teknik modeling statistik yang bersifat sangat cross-sectional, linear dan umum. Termasuk dalam SEM ini ialah analisis faktor (factor analysis), analisis jalur (path analysis), dan regresi (regression). Teknik analisis ini memungkinkan peneliti untuk menguji hubungan antara variabel yang bersifat kompleks yang bertujuan untuk memperoleh gambaran menyeluruh mengenai suatu model secara keseluruhan (Ghozali dan Fuad, 2008).

Pengembangan diagram jalur dalam penelitian ini berupaya menguji pengaruh kredibillitas, kepercayaan, risk, internet use terhadap kegunaan yang dirasakan (perceived usefulness), kemudahan penggunaan (perceived ease of use), dan pada akhirnya pengaruh pada niat responden dalam melakukan transaksi ulang melalui e-commerce mobile platform.
Variabel yang digunakan pada model penelitian ini adalah sebanyak tujuh variabel di mana terdapat empat variabel independen, dua mediator, dan satu variabel dependen. Pada Tabel 1 menunjukkan operasionalisasi tiap variabel di mana credibility diukur dengan menggunakan tiga indikator, trust diukur dengan empat indikator, risk dan internet use diukur oleh 3 indikator, perceived usefuleness dan perceived ease of use masingmasing diukur dengan empat indikator, serta intention menggunakan tiga indikator.

Selanjutnya, kerangka pemikiran (Gambar 1) dalam penelitian ini berupa mengembangkan anteseden TAM melalui analisis empat faktor atau independent variable dalam studi ini, yakni kredibilitas, kepercayaan, risk, dan internet use. Credibility dan trust merupakan konsep yang saling terkait dan sering diterapkan secara bergantian, tetapi masing-masing memiliki perbedaan. Trust sangat erat kaitannya dengan bagaimana individu berhubungan dengan risiko dan ketidakpastian. Untuk mendapatkan sebuah kepercayaan atau trust, maka seseorang butuh memiliki kredibilitas (atau dapat dipercaya yang secara harfiah layak dipercaya), karena kredibilitas merupakan persepsi dari individu lainnya (Thorsøe, 2015). Pada sejumlah penelitian tersebut terbukti bahwa credibility memainkan peran penting dan memberikan pengaruh positif terhadap perceived ease of use, dan perceived usefulness (Baogoza dan Ozer, 2012).

Trust merupakan keyakinan perilaku yang telah dipelajari dalam konteks e-commerce dan terbukti memiliki efek positif terhadap niat konsumen untuk menggunakan teknologi (Schnalla et al. 2015). Trust merupakan keyakinan bahwa pihak lain akan berperilaku secara bertanggung jawab dan tidak akan mencoba untuk mengeksploitasi kerentanan pengguna (Pavlou, 2003). Dalam studi yang dilakukan oleh Schnalla et al. (2015) mengungkapkan bahwa integrasi pada empat variabel independen (trust, perceived risk, perceived usefulness, dan perceived ease of use) hubungan di antaranya telah tervalidasi dengan baik. Trust memiliki hubungan dengan perceived ease of use karena hal tersebut dapat mengurangi upaya yang seharusnya diperlukan untuk memonitor fungsi dari suatu sistem. Trust juga terkait dengan risiko yang dirasakan karena tingkat kepercayaan yang lebih tinggi dalam entitas online mampu mengurangi persepsi risiko selama interaksi berlangsung (Schnalla et al. 2015). 
Tabel 1. Definisi operasional variabel

\begin{tabular}{llcc}
\hline \multicolumn{1}{c}{ Variabel } & \multicolumn{1}{c}{ Definisi Operasional } & $\begin{array}{c}\text { Jumlah } \\
\text { Indikator }\end{array}$ & Skala \\
\hline Credibility & $\begin{array}{l}\text { Kredibilitas (atau dapat dipercaya yang secara harfiah layak dipercaya), karena } \\
\text { kredibilitas merupakan persepsi dari individu lainnya (Thorsøe, 2015). } \\
\text { Kepercayaan diri konsumen ataupun pelanggan pada merek tertentu yang dapat } \\
\text { memuaskan keinginan pelanggan (Rachbini, 2018). }\end{array}$ & 3 \\
& $\begin{array}{l}\text { Resiko dari kerugian moneter, karena konsumen harus mengandalkan informasi } \\
\text { elektronik, dan resiko terkait kehilangan privasi yang terkait dengan informasi data } \\
\text { pribadi pengguna ke pengelola web (Lee, 1998; Culnan dan Armstrong, 1999). }\end{array}$ & 3 & \\
Risk & $\begin{array}{l}\text { Penggunaan internet yang dilakukan oleh individu atau konsumen, khususnya lama } \\
\text { penggunaan internet dan daily internet usage (Saade dan Kira, 2006) }\end{array}$ & 3 & Skala \\
Internet use & 4 & Likert \\
$\begin{array}{l}\text { Perceived } \\
\text { usefuleness }\end{array}$ & $\begin{array}{l}\text { Suatu tingkat dimana seseorang mampu percaya bahwa dengan menggunakan } \\
\text { teknologi tertentu dapat meningkatkan kinerja pekerjaan mereka (Davis, 1989). }\end{array}$ \\
$\begin{array}{l}\text { Perceived } \\
\text { ease of use }\end{array}$ & $\begin{array}{l}\text { Sejauh mana seseorang percaya atau yakin bahwa dengan menggunakan sistem } \\
\text { tertentu, maka akan mengurangi effort dari pengguna tersebut (Davis, 1989). }\end{array}$ \\
$\begin{array}{l}\text { Intention } \\
\text { for online } \\
\text { transactions }\end{array}$ & $\begin{array}{l}\text { Niat yang timbul dari proses pembelajaran dan penyelesaian masalah pada diri calon } \\
\text { konsumen dalam menentukan keputusan untuk memilih atau menggunakan suatu } \\
\text { merek atau produk (Rachbini, 2017). }\end{array}$ & 4 \\
\hline
\end{tabular}

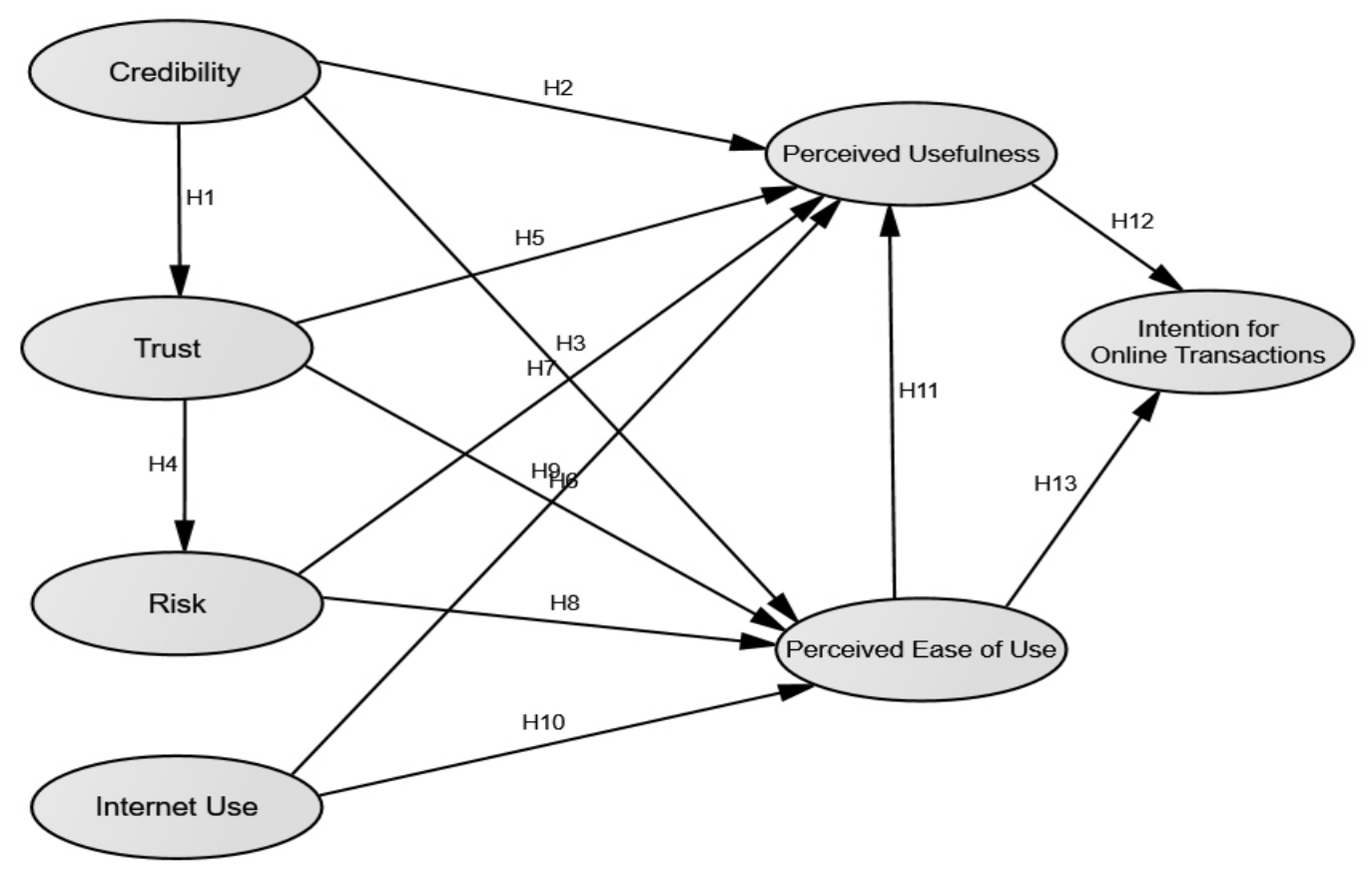

Gambar 1. Kerangka pemikiran penelitian

Featherman dan Hajli (2016) mengungkapkan bahwa penilaian konsumen terhadap risiko memengaruhi evaluasi pada layanan berbasis elektronik dan pembelian ketika kerugian pribadi terjadi dan menciptakan ketidaknyamanan secara psikologis dan atau kecemasan (Dowling dan Staelin, 1994). Penelitian terkait dengan service berhasil membuktikan bahwa konsumen yang tidak dapat menilai kinerja suatu layanan, maka merasa memiliki risiko lebih tinggi (Murray, 1991). Tingkat risiko penggunaan yang lebih tinggi dapat memperburuk evaluasi konsumen terhadap kegunaan (usefulness) pelayanan berbasis elektronik dan juga menghambat penggunaan (ease of use) pelayanan tersebut (Featherman dan Hajli, 2016).

TAM secara khusus dikembangkan untuk menganalisa keinginan pengguna untuk menerima dan menggunakan teknologi ataupun media baru dalam konteks manajemen sistem informasi (Ma et al. 2017). Dewasa ini, TAM telah diterapkan secara luas untuk menjelaskan penggunaan teknologi oleh konsumen dalam konteks belanja online (Cho dan Wang, 2010; 
Kim et al. 2009; Kim dan Forsythe, 2008). Ma et al. (2017) mengungkapkan bahwa kemudahan penggunaan (perceived ease of use) dan kegunaan (perceived usefulness) berkontribusi pada pembentukan sikap pengguna dalam menggunakan teknologi yang pada akhirnya berdampak pada meningkatnya niat pengguna untuk menggunakan suatu teknologi. Selain itu, perceived ease of use juga disebut memiliki pengaruh positif terhadap persepsi individu terkait dengan kegunaan dalam menggunakan teknologi (perceived usefulness) (Ma et al. 2017).

\section{HASIL}

Model penelitian yang digambarkan pada Gambar 1 dianalisis dengan menggunakan pendekatan model persamaan struktural (SEM) melalui alat analisis AMOS. Untuk mengetahui ketepatan model pengukuran, digunakan model analisis faktor konfirmatori confirmatory factor analysis (CFA). CFA memiliki dua fokus kajian, yaitu (1) apakah indikatorindikator yang dikonsepsikan secara unidimensional valid, (2) indikator-indikator apa yang dominan membentuk konstruk yang diteliti.

Mengacu pada Tabel 2 maka diketahui bahwa nilai standardized regression atau factor loading masingmasing indikator menunjukkan nilai $\geq 0,60$. Hal ini merepresentasikan bahwa seluruh indikator yang digunakan dalam penelitian ini valid atau dengan kata lain mampu mengukur masing-masing konstruk. Indikator kedua dari credibility (e-commerce mobile platform merupakan tempat yang kredibel untuk berbelanja) merupakan indikator dengan bobot besaran factor loading terkuat di mana memiliki nilai factor loading sebesar 0,924. Sementara itu, nilai factor loading terendah terdapat pada indikator ketiga dalam konstruk internet $u$ se (aktif menggunakan internet setia saat) dengan nilai factor loading hanya sebesar 0,606. Selanjutnya, model SEM dianalisis untuk mengetahui apakahmemilikiderajatkecocokan (goodnessoffit) yang baik dengan data yang diambil dari sampel yang diteliti sehingga model yang dihasilkan dapat menjelaskan data yang diperoleh. Penilaian uji kecocokan model secara keseluruhan pada penelitian ini dapat dikatakan fit karena terdapat beberapa ukuran goodness of ft yang sudah memenuhi persyaratan atau dengan kata lain model yang dibangun dapat menjelaskan informasi empiris mengenai data yang dikumpulkan. Tabel 3 menunjukkan bahwa secara keseluruhan model SEM penelitian ini merupakan fit model yang dapat diterima atau layak digunakan. Hasil uji Goodness of Fit Full Model - Standardized Regression Weight pada Gambar 2.

\section{Pengujian Hubungan antar Variabel berdasarkan Hipotesis Penelitian}

Setelah mengetahui kecocokan model secara keseluruhan maka selanjutnya dilakukan analisis lebih lanjut untuk melihat tingkat signifkasi antar variabel. Tingkat signifkasi hubungan antar variabel dapat dilihat melalui tingkat signifkasi $\alpha=0,05 \quad(\mathrm{t} \alpha / 2=1,96)$ yang terangkum pada Tabel 4.

Tabel 2. Confirmatory Factor Analysis (CFA)

\begin{tabular}{lcc}
\hline Keterangan & Estimate & CR (T-Value) \\
\hline Internet_Use (IUSE3) &, 678 & 6,201 \\
Internet_Use (IUSE2) &, 903 & 6,322 \\
Internet_Use (IUSE1) &, 606 & 6,471 \\
Credibility (CRED3) &, 898 & 14,021 \\
Credibility (CRED2) &, 924 & 17,046 \\
Credibility (CRED1) &, 831 & 13,854 \\
Trust (TRST4) &, 799 & 12,243 \\
Trust (TRST3) &, 862 & 12,201 \\
Trust (TRST2) &, 876 & 12,498 \\
Trust (TRST1) &, 812 & 11,241 \\
Risk (RISK3) &, 796 & 11,212 \\
Risk (RISK2) &, 910 & 11,933 \\
Risk (RISK1) &, 736 & 9,514 \\
Usefulness (USEF1) &, 713 & 6,501 \\
Usefulness (USEF2) &, 607 & 6,383 \\
Usefulness (USEF3) &, 653 & 6,801 \\
Usefulness (USEF4) &, 663 & 6,891 \\
Intention_2online (PAY1) &, 819 & 11,813 \\
Intention_2online (PAY2) &, 837 & 11,956 \\
Intention_2online (PAY3) &, 844 & 12,103 \\
Ease_ofUse (EUSE4) &, 846 & 10,201 \\
Ease_ofUse (EUSE3) &, 728 & 10,410 \\
Ease_ofUse (EUSE2) &, 846 & 13,168 \\
Ease_ofUse (EUSE1) &, 884 & 14,219 \\
\hline & &
\end{tabular}


Tabel 3. Goodness-of-fit Model

\begin{tabular}{cccc}
\hline Goodness-Of-Fit & Hasil Analisis & Cut Off Value & Evaluasi Model \\
\hline Chi-square & $\gamma=422,016, \mathrm{P}=0,000$ & Probabilitas $\geq 0,05$ & Kurang Baik \\
TLI & 0,916 & TLI $>0,90$ & Baik \\
GFI & 0,809 & GFI $>0,90$ & Mendekati \\
AGFI & 0,759 & AGFI $>0,90$ & Kurang Baik \\
CFI & 0,928 & CFI $>0,90$ & Baik \\
RMSEA & 0,072 & RMSEA $\leq 0,08$ & Baik \\
\hline
\end{tabular}

Tabel 4. Hasil uji hipotesis penelitian

\begin{tabular}{|c|c|c|c|}
\hline Hipotesis Penelitian & Koefisien Regresi & CR (T-Value) & $\mathrm{P}$ \\
\hline H1:Terdapat pengaruh signifikan credibility terhadap trust &, 722 & 9,730 & $* * *$ \\
\hline H2:Terdapat pengaruh signifikan credibility terhadap perceived usefulness & ,816 & 8,762 & $* * *$ \\
\hline H3:Terdapat pengaruh signifikan credibility terhadap perceived ease of use & 078 & 1,093 & 274 \\
\hline H4: Terdapat pengaruh signifikan trust terhadap risk & 247 & 2,562 & 010 \\
\hline H5: Terdapat pengaruh signifikan trust terhadap perceived usefulness & ,729 & 4,356 & $* * *$ \\
\hline H6: Terdapat pengaruh signifikan trust terhadap perceived ease of use &,- 089 &,- 738 & ,461 \\
\hline H7: Terdapat pengaruh signifikan risk terhadap perceived usefulness &,- 045 &,- 536 & ,592 \\
\hline H8: Terdapat pengaruh signifikan risk terhadap perceived ease of use & ,241 & 2,068 & 039 \\
\hline $\begin{array}{l}\text { H9: Terdapat pengaruh signifikan internet use terhadap perceived } \\
\text { usefulness }\end{array}$ & ,799 & 3,235 & ,001 \\
\hline $\begin{array}{l}\text { H10: Terdapat pengaruh signifikan internet use terhadap perceived ease of } \\
\text { use }\end{array}$ & ,282 & 1,916 & 055 \\
\hline $\begin{array}{l}\text { H11: Terdapat pengaruh signifikan perceived ease of use terhadap } \\
\text { perceived usefulness }\end{array}$ &, 860 & 5,059 & $* * *$ \\
\hline $\begin{array}{l}\text { H12: Terdapat pengaruh signifikan perceived usefulness terhadap intention } \\
\text { for online transactions }\end{array}$ &,- 158 & $-1,386$ &, 166 \\
\hline $\begin{array}{l}\text { H13: Terdapat pengaruh signifikan perceived ease of use terhadap intention } \\
\text { for online transactions }\end{array}$ & 1,036 & 9,243 & $* * *$ \\
\hline
\end{tabular}

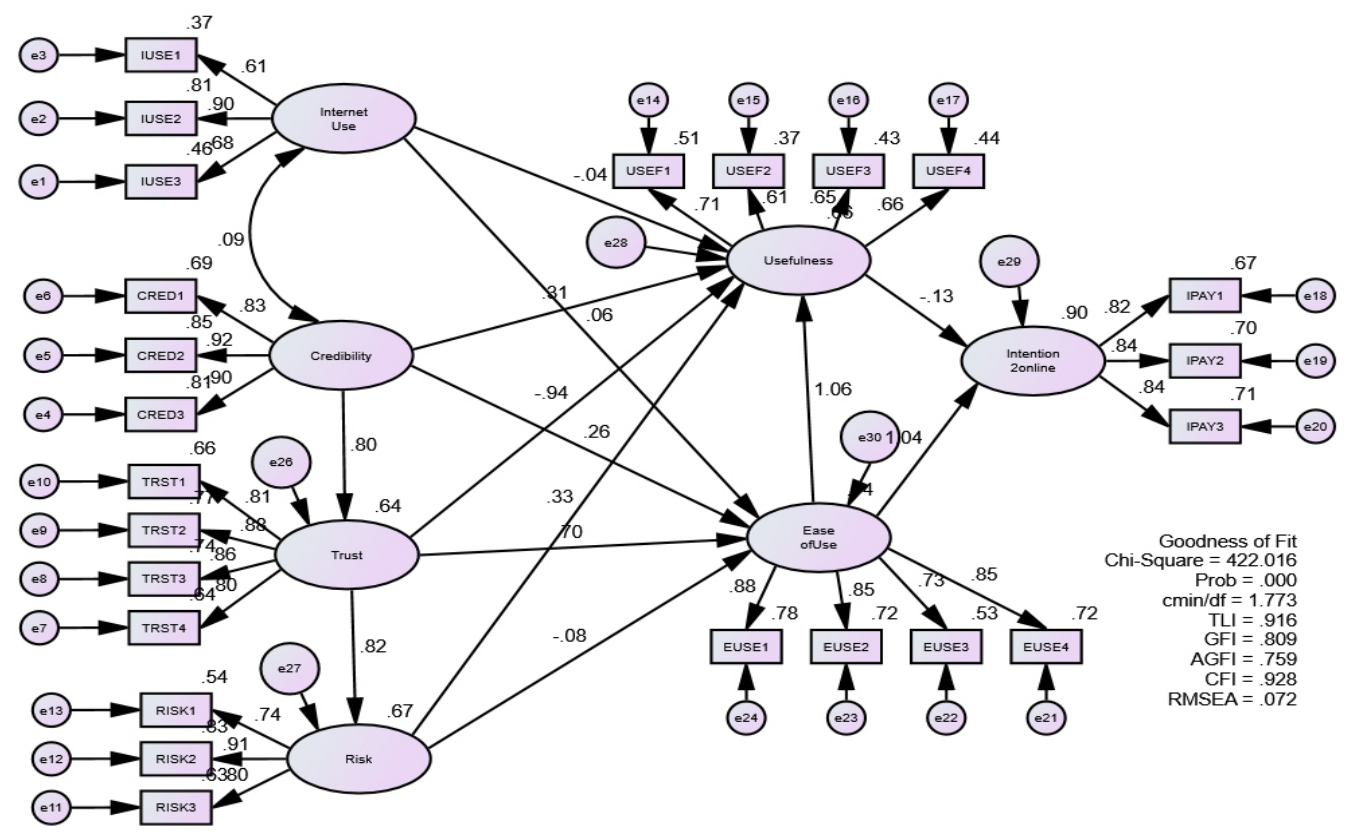

Gambar 2. Goodness of Fit Full Model - Standardized Regression Weight 
H1:Terdapat pengaruh signifikan credibility terhadap trust.

Hasil pengujian hipotesis pertama menunjukkan nilai $\rho$-value sebesar $0,000<0,05$ serta nilai Critical Ratio (CR) sebesar 9,730 > 1,96 maka hasil ini menunjukkan bahwa H0 tidak didukung dan H1 didukung, yang berarti terdapat pengaruh credibility terhadap trust. Hasil ini membuktikan bahwa hipotesis pertama dapat diterima. Semakin meningkat credibility, maka semakin meningkat pula trust. Credibility dan trust merupakan konsep yang saling terkait dan sering diterapkan secara bergantian, tetapi masing-masing memiliki perbedaan. Trust sangat erat kaitannya dengan bagaimana individu berhubungan dengan risiko dan ketidakpastian. Untuk mendapatkan sebuah kepercayaan atau trust maka seseorang butuh memiliki kredibilitas (atau dapat dipercaya yang secara harfiah layak dipercaya), karena kredibilitas merupakan persepsi dari individu lainnya (Thorsøe, 2015).

H2: Terdapat pengaruh signifikan credibility terhadap perceived usefulness

Hasil pengujian hipotesis kedua menunjukkan nilai $\rho$-value sebesar $0,039<0,05$ serta nilai Critical Ratio (CR) sebesar 2,068 >1,96, maka hasil ini menunjukkan bahwa H0 tidak didukung dan $\mathrm{H} 2$ didukung, yang berarti terdapat pengaruh credibility terhadap perceived usefulness. Hasil temuan dalam hipotesis kedua ini konsisten atau sejalan dengan beberapa penelitian terdahulu yang dilakukakan oleh McKnight dan Kacmar, (2007). Pada sejumlah penelitian tersebut terbukti juga bahwa credibility memainkan peran penting dan memberikan pengaruh positif terhadap perceived ease of use, maupun perceived usefulness (Baogoza dan Ozer, 2012).

H3: Terdapat pengaruh signifikan credibility terhadap perceived ease of use

Hasil pengujian hipotesis ketiga menunjukkan nilai $\rho$-value sebesar $0,010<0,05$, serta nilai Critical Ratio (CR) sebesar 2,562>1,96, maka hasil ini menunjukkan bahwa H0 tidak didukung dan H3 didukung, yang berarti terdapat pengaruh signifikan credibility terhadap perceived ease of use. Hasil ini konsisten mendukung sejumlah studi terdahulu, salah satunya ialah penelitian yang dilakukan oleh Baogoza dan Ozer, (2012) yang menegaskan bahwa credibility berpengaruh positif dan signifikan terhadap perceived ease of use. McKnight dan Kacmar, (2007) pun menyatakan bahwa mengacu pada TAM maka credibility berperan pada perceived ease of use.

\section{H4: Terdapat pengaruh signifikan trust terhadap risk}

Hasil pengujian hipotesis keempat menunjukkan nilai $\rho$-value sebesar $0,000<0,05$, serta nilai Critical Ratio (CR) sebesar 8,762>1,96, maka hasil ini menunjukkan bahwa H0 tidak didukung dan H4 didukung, yang berarti terdapat pengaruh signifikan trust terhadap risk. Pentingnya trust atau kepercayaan meningkat ketika ada tingkat ketidakpastian yang tinggi yang terjadi ketika pengguna tidak memahami di mana informasi mereka disimpan atau bagaimana informasi itu dikirimkan (Schnalla et al. 2015). Hasil pada penelitian ini konsisten mendukung studi terdahulu yang dilakukan oleh Schnalla et al. (2015) yang mengungkapkan bahwa trust berpengaruh signifikan terhadap perceived risk.

H5: Terdapat pengaruh signifikan trust terhadap perceived usefulness

Hasil pengujian hipotesis kelima menunjukkan nilai $\rho$-value sebesar $0,001<0,05$, serta nilai Critical Ratio (CR) sebesar 3,235 > 1,96 maka hasil ini menunjukkan bahwa H0 tidak didukung dan H5 didukung, yang berarti terdapat pengaruh signifikan trust terhadap perceived usefulness. Dalam penelitian ini kepercayaan sangat memengaruhi kegunaan yang dirasakan dalam transaksi elektronik. Trust merupakan variabel yang menentukan dari sebagian besar interaksi elektronik. Hasil temuan ini konsisten mendukung penelitian yang dilakukan oleh Schnalla et al. (2015) yang sebelumnya berhasil membuktikan bahwa trust memainkan peranan penting dalam memengaruhi perceived usefulness.

H6: Terdapat pengaruh signifikan trust terhadap perceived ease of use

Hasil pengujian hipotesis keenam menunjukkan nilai $\rho$-value sebesar $0,000<0,05$ serta nilai Critical Ratio (CR) sebesar 4,356>1,96, maka hasil ini menunjukkan bahwa $\mathrm{H} 0$ tidak didukung dan $\mathrm{H} 6$ didukung, yang berarti terdapat pengaruh signifikan trust terhadap perceived ease of use. Hasil pada penelitian ini sejalan dengan studi yang dilakukan oleh Schnalla et al. (2015) yang mengungkapkan bahwa trust berpengaruh positif dan signifikan terhadap konstruk perceived ease of use. 
H7: Terdapat pengaruh signifikan risk terhadap perceived usefulness

Hasil pengujian hipotesis ketujuh menunjukkan nilai $\rho$-value sebesar 0,055>0,05 serta nilai Critical Ratio (CR) sebesar 1,91<1,96 maka hasil ini menunjukkan bahwa H0 didukung dan $\mathrm{H} 7$ tidak didukung, yang berarti tidak terdapat pengaruh signifikan risk terhadap perceived usefulness. Hasil temuan ini konsisten mendukung penelitian yang dilakukan oleh Groot, (2018) yang dengan tegas menyakatan bahwa tidak terdapat pengaruh signifikan antara risk dan perceived usefulness dalam konteks consumer acceptance of 3D food printing. Hasil tersebut merepresentasikan tidak terdapat keterhubungan persepsi individu pada risiko dengan kegunaan dalam menggunakan teknologi.

H8: Terdapat pengaruh signifikan risk terhadap perceived ease of use

Hasil pengujian hipotesis kedelapan menunjukkan nilai $\rho$-value sebesar 0,461 $>0,05$ serta nilai Critical Ratio (CR) sebesar - $0,738<1,96$ maka hasil ini menunjukkan bahwa $\mathrm{H} 0$ didukung dan $\mathrm{H} 8$ tidak didukung, yang berarti tidak terdapat pengaruh signifikan risk terhadap perceived ease of use. Perkembangan teknologi dan informasi mendorong berbagai kegiatan transaksi melalui jaringan internet. Berbagai platform layanan internetmulaibermunculandenganberbagaikemudahan dan juga risikonya. Hasil ini secara implisit dan konsisten mendukung beberapa penelitian terdahulu di mana dalam penelitian ini risk secara definisi mengacu pada studi yang dilakukan oleh Lee (1998); Culnan dan Armstrong (1999) yang mengungkapkan bahwa risk merupakan persepsi terkait terdapatnya risiko dari kerugian moneter, dan risiko kehilangan privasi yang terkait dengan informasi data pribadi pengguna (baik sengaja atau tidak sadar) ke pengelola web.

H9: Terdapat pengaruh signifikan internet use terhadap perceived usefulness

Hasil pengujian hipotesis kesembilan menunjukkan nilai $\rho$-value sebesar 0,592>0,05 serta nilai Critical Ratio (CR) sebesar -0,536 <1,96 maka hasil ini menunjukkan bahwa H0 didukung dan H9 tidak didukung, yang berarti tidak terdapat pengaruh signifikan internet use terhadap perceived usefulness. Hasil temuan ini konsisten mendukung penelitian sebelumnya yang dilakukan oleh Danurdoro (2016) yang mengungkapkan bahwa peningkatan penetrasi internet dan pengguna internet memberikan efek pada semua bidang, khususnya pada responden dalam penelitiannya yang saat ini menggunakan transaksi perbankan. Namun, faktanya ketersediaan dan manfaat internet banking service belum dirasakan oleh semua responden dikarenakan para responden memiliki pengetahuan dan kebutuhan yang berbeda-beda. Di sisi lain, pihak perbankan dinilai harus mampu mensosialisasikan dan mempromosikan melalui media sosial untuk meningkatkan pengetahuan para responden.

H10: Terdapat pengaruh signifikan internet use terhadap perceived ease of use

Hasil pengujian hipotesis kesepuluh menunjukkan nilai $\rho$-value sebesar 0,274 $>0,05$ serta nilai Critical Ratio (CR) sebesar 1,09<1,96 maka hasil ini menunjukkan bahwa H0 didukung dan H10 tidak didukung, yang berarti tidak terdapat pengaruh signifikan internet use terhadap perceived ease of use. Dalam penelitian terdahulu yang dilakukan oleh Saade dan Kira, (2006) menunjukkan bahwapengalaman menggunakaninternet (time spent dan daily internet usage) berpengaruh positif signifikan terhadap kemudahan penerimaan pada konteks online learning system, bukan pada hal yang terkait dengan online transactions ataupun berbelanja secara online melalui mobile platform. Dengan demikian perbedaan unit analisis penelitian sangat memengaruhi output riset yang terkait dengan penggunaan internet, dan TAM.

H11: Terdapat pengaruh signifikan perceived ease of use terhadap perceived usefulness.

Hasil pengujian hipotesis kesebelas menunjukkan nilai $\rho$-value sebesar $0,00<0,05$ serta nilai Critical Ratio (CR) sebesar 5,05 > 1,96, maka hasil ini menunjukkan bahwa H0 tidak didukung dan H11 didukung, yang berarti terdapat pengaruh signifikan perceived ease of use terhadap perceived usefulness. Hasil penelitian ini sejalan dengan studi terdahulu yang dikemukakan oleh Ma et al. (2017) yang mengungkapkan bahwa perceived ease of use memiliki pengaruh positif signifikan terhadap persepsi individu terkait dengan kegunaan dalam menggunakan teknologi (perceived usefulness). 
H12: Terdapat pengaruh signifikan perceived usefulness terhadap intention for online transactions.

Hasil pengujian hipotesis 12 menunjukkan nilai $\rho$-value sebesar 0,166 > 0,05 serta nilai Critical Ratio (CR) sebesar $-1,386>1,96$ maka hasil ini menunjukkan bahwa H0 didukung dan H12 tidak didukung, yang berarti tidak terdapat pengaruh signifikan perceived usefulness terhadap intention for online transactions. Hasil temuan ini konsisten mendukung penelitian terdahulu yang dilakukan oleh Juniwati (2014) di mana dalam studinya tersebut memiliki kesamaan dengan studi ini. Penelitian tersebut berfokus pada determinan intention to shop online, dan terbukti bahwa perceived usefulness tidak berperan signifikan dalammemengaruhi online intention, hal ini disebabkan oleh aspek kultur di mana kecenderungan individu yang lebih memilih menghabiskan waktu untuk bersosialisasi untuk mengembangkan hubungan sosial. Dampak budaya pada perilaku adopsi merupakan salah satu hal utama dalam penelitian untuk diselidiki (Lok, 2015).

H13: Terdapat pengaruh signifikan perceived ease of use terhadap intention for online transactions.

Hasil pengujian hipotesis 13 menunjukkan nilai $\rho$-value sebesar $0,000<0,05$ serta nilai Critical Ratio (CR) sebesar 9,24>1,96, maka hasil ini menunjukkan bahwa H0 tidak didukung dan H13 didukung, yang berarti terdapat pengaruh signifikan perceived ease of use terhadap intention for online transactions. Hasil penelitian ini konsisten mendukung beberapa penelitian terdahulu terkait dengan TAM. Pertama, temuan ini mendukung studi yang dilakukan oleh Vijayasarathy (2004) yang melakukan riset terkait niat perilaku konsumen untuk melakukan belanja online. Ia berhasil membuktikan bahwa perceived ease of use secara signifikan berpengaruh terhadap sikap dan niat perilaku konsumen untuk melakukan belanja online.

Selain itu, mengacu pada Tabel 5, maka menunjukkan nilai indirect effect dalam penelitian ini. Penelitian ini termasuk dalam kategori full mediation dikarenakan tidak menguji secara langsung variabel-variabel eksogen seperti credibility, trust, risk, dan internet use terhadap intention. Pengaruh tidak langsung tersebar adalah pengaruh trust terhadap intention melalui perceived ease of use dengan nilai indirect effect sebesar 0,728. Sementara itu, indirect effect dengan nilai terendah adalah pengaruh internet use terhadap intention melalui perceived usefulness dengan nilai indirect effect sebesar 0,005 .

\section{Implikasi Manajerial}

Berdasarkan temuan dalam penelitian ini, maka tentunya berimplikasi pada dunia praktis atau dengan kata lain memberikan implikasi manajerial dalam dunia e-commerce untuk dapat terus meningkatkan dan mengembangkan hal-hal terkait dengan TAM. Pertama, para pemangku kepentingan, khusunya tim manajemen dan tim IT harus memberikan perhatian lebih pada aspek kredibilitas, kepercayaan, dan risk. Tiga aspek tersebut terbukti saling memberikan pengaruh, maka pihak management yang dalam hal ini marketing department harus mampu mengkomunikasikan dan mempromosikan tiga hal tersebut dengan baik dan tepat sasaran agar mampu dipahami dan dapat meyakinkan konsumen bahwa e-commerce merupakan tempat berbelanja yang kredibel (dapat dipercaya), dan aman. Di sisi lain, tim IT dalam konteks ini juga harus dapat menjaga kredibilitas, kepercayaan, dan pengelolaan risiko melalui pengembangan mobile platform yang dapat meminimalisir hal-hal yang tidak diinginkan guna menjaga kredibilitas dan kepercayaan konsumen terhadap e-commerce.

Kedua, demi meningkatkan manfaat saat bertransaksi, dan niat melakukan pembelian ulang atau transaksi di e-commerce platform maka update fitur dan kemudahan dalam bertransaksi harus berfokus pada penyederhanaan customer journey di mana pelanggan dapat memilih produk sesuai dengan preferensi maupun budget yang dimiliki, langkah selanjutnya opsi diskon, cashback, asuransi, layanan pengiriman, dan payment channel yang lengkap dapat tersaji secara sistematis serta harus mudah dipahami oleh para pelanggan. Selain itu, untuk lebih memudahkan aktivitas pembelian di e-commerce, maka layanan call center via telepon maupun online chatting harus tersedia agar dapat semakin memudahkan pelanggan mendapatkan informasi dan solusi yang dibutuhkan.

\section{KESIMPULAN DAN SARAN}

Temuan dalam penelitian ini menunjukkan bahwa terdapat pengaruh signifikan credibility terhadap trust, dan pengaruh signifikan trust terhadap risk. Selanjutnya, credibility, trust memberikan pengaruh 
signifikan terhadap perceived ease of use, dan juga terdapat pengaruh signifikan credibility, trust terhadap perceived usefulness. Sementara itu, perceived ease of use berperan signifikan dalam memengaruhi perceived usefulness serta perceived ease of use berpengaruh signifikan terhadap intention to online transactions. Kredibilitas, kepercayaan, risiko, dan penggunaan internet secara umum dihipotesiskan sebagai anteseden terhadap kegunaan yang dirasakan dan kemudahan penggunaan yang berperan sebagai prediktor utama pada penerimaan teknologi baru. Niat bertransaksi melalui internet merupakan variabel dependen dalam penelitian ini. Dari sejumlah hasil temuan yang telah diuraikan di atas menunjukkan bahwa kepercayaan, kredibilitas dan risiko merupakan sejumlah faktor penting bagi interpersonal maupun hubungan komersial.

\section{Saran}

Selain itu, penelitian ini tentunya memiliki beberapa keterbatasan, yakni unit analisis data hanya berfokus pada pengguna atau pelanggan yang melakukan transaksi melalui e-commerce mobile platform. Selanjutnya, studi ini juga hanya dilakukan di DKI Jakarta dan e-commerce yang diteliti merupakan $\mathrm{C} 2 \mathrm{C}$ e-commerce. Dengan demikian, diharapkan untuk peneliti selanjutnya dapat dapat melakukan penelitian dalam konteks website, social media platform ataupun tablet apps seperti yang dilakukan oleh Kim, (2016) pada industri perhotelan, serta diharapkan dapat dilakukan penelitian di kota besar lainnya dan dapat berfokus pada $\mathrm{B} 2 \mathrm{C}$ e-commerce.

\section{DAFTAR PUSTAKA}

Aladwani AM. 2003. Key internet characteristics and e-commerce issues in Arab countries. Information Technology and People 16 (1): 9-20. https://doi. org/10.1108/09593840310462998.

Andoh CB. 2018. Predicting students' intention to adopt mobile learning: A combination of theory of reasoned action and technology acceptance model. Journal of Research in Innovative Teaching \& Learning 11(2): 178-191.https:// doi.org/10.1108/JRIT-03-2017-0004.

Baogoza P, Ozer L. 2012. Effects of brand credibility on technology acceptance model: adaption of the model to the purchase intention. International Journal of Humanities and Social Science 2(20):292-298.
Bernadette S. 1996. Empirical evaluation of the revised technology acceptance model. Management Science 42(1): 85-93. https://doi.org/10.1287/ mnsc. 42.1 .85

Correa R, Arenas-Gaitán J, Rondán-Cataluña FJ. 2015. Gender and acceptance of e-learning: a multigroup analysis based on a structural equation model among college students in Chile and Spain. PLoS ONE 10(10). https://doi.org/10.1371/ journal.pone. 0140460

Culnan MJ, Armstrong PK.1999. Information privacy concerns, procedural fairness, and impersonal trust: an empirical investigation. Organization Science 10 (1): 104-115. https://doi.org/10.1287/ orsc.10.1.104

Danurdoro K. 2016. The impact of perceived usefulness, perceived ease of use, subjective norm, and experience toward student's intention to use internet banking. Jurnal Ekonomi dan Studi Pembangunan 8(1). https://doi.org/10.17977/ um002v8i12016p017

FeathermanMS,HajliN.2016. Self-servicetechnologies and e-services risks in social commerce era. Journal of Business Ethics 139:251-269. https:// doi.org/10.1007/s10551-015-2614-4.

Gefen D, StraubD. 2002. Managing user trust in e-services. e-Service Journal 2(1).

Groot S. 2018. Effect of Perceived Risks, Naturalness, Usefulness and Ease of Use on the Consumer Acceptance of $3 D$ Food Printing. Wageningen UR.

Holden RJ, Asan O, Wozniak EM, Flynn KE, Scanlon M. 2016. Nurses' perceptions, acceptance, and use of a novel in-room pediatric ICU technology: testing an expanded Technology Acceptance Model. BMC Medical Informatics and Decision Making 16:145. https://doi.org/10.1186/s12911016-0388-y.

Hootsuite. 2018. Indonesia Digital Landscape: A Snapshot of The Country's Key Digital Statistical Indicators.

Internetworldstats. 2018. Diakses dari: https://www. internetworldstats.com/stats.htm.

Indrayana B, Seminar KB, Sartono B. 2016. Faktor penentu penggunaan instagram untuk pembelian online menggunakan Technology Acceptance Model (TAM) dan Theory of Planned Behavior (TPB). Jurnal Aplikasi Bisnis dan Manajemen 2(2):138-147.https://doi.org/10.17358/ JABM.2.2.138.

Juniwati. 2014. Influence of perceived usefulness, 
ease of use, risk on attitude and intention to shop online. European Journal of Business and Management 6(27).

Kim JS. 2016. An extended technology acceptance model in behavioral intention toward hotel tablet apps with moderating effects of gender and age. International Journal of Contemporary Hospitality Management 28(8): 1535-1553. https://doi.org/10.1108/IJCHM-06-2015-0289.

LeeHG. 1998. Doelectronic marketplaces lowertheprice of goods? Communications of the ACM 41(1):7380.https://doi.org/10.1145/268092.268122.

Lok CK. 2015. Adoption of smart card-based e-payment system for retailing in hong kong using an extended technology acceptance model. In E-services Adoption: Processes by Firms in Developing Nations. https://doi.org/10.1108/ S1069-09642015000023B003.

Ma Y, Gam HJ, Banning J. 2017. Perceived ease of use and usefulness of sustainability labels on apparel products: application of the Technology Acceptance Model. https://doi.org/10.1186/ s40691-017-0093-1.

Mcknight D, Kacmar C. 2007. Factors and effects of information credibility. ACM International Conference Proceeding Series 258: 423-432. https://doi.org/10.1145/1282100.1282180.

Ngiam WS, Chaiyasoonthorn W. 2011. Development of technology acceptance model explaining thai students. International Journal of Arts \& Sciences 4(25):249-267.

Park. 2016. The adoption of teaching assistant robots: A technology acceptance model approach".https:// doi.org/10.1108/PROG-02-2016-0017.

Pavlou PA. 2003. Consumer acceptance of electronic commerce. Integrating trust and risk with the Technology Acceptance Model. International Journal of Electronic Commerce 7(3): 101-134. https://doi.org/10.1080/10864415.2003.110442 75.

Rachbini W. 2017. Peran social support terhadap relationship quality dan social commerce intention. MIX: Jurnal Ilmiah Manajemen VII(3): $330-347$.
Rachbini W. 2018. The impact of consumer trust, perceived risk, perceived benefit on purchase intention and purchase decision. International Journal of Advanced Research 6(1):1036-1044. https://doi.org/10.21474/IJAR01/6317.

Saade RG, Kira D. 2006. Mediating the impact of technology usage on perceived ease of use by anxiety. Journal of Computers \& Education 49:1189-1204.https://doi.org/10.1016/j. compedu.2006.01.009.

Salman A, Abdullah M, Aziz J, Ahmad AL, Kee CP. 2014. Remodelling Technology Acceptance Model in Explaining User Acceptence towards Information and Communication Technology. International Journal of Arts and Sciences 7(1):159-171.

Schnalla R, Higgins T, Brown W, Dieguez A, Bakkena S. 2015. Trust, perceived risk, perceived ease of use and perceived usefulness as factors related to mhealth technology use. Stud Health Technol Inform 216: 467-471.

Stewart DW, Pavlou PA, Ward S. 2002. Media influences on marketing communications. In: Bryant, J., Zillmann, D. (Eds.), Media Effects: Advances in Theory and Research. Erlbaum, Hillsdale, NJ, pp. 353-396.

Thorsøe M. 2015. Maintaining trust and credibility in a continuously evolving organic food system. Journal of Agricultural and Environmental Ethics 28:767-787. DOI 10.1007/s10806-0159559-6.https://doi.org/10.1007/s10806-0159559-6.

Venkatesh V, Davis FD.2000. A theoretical extension of the technology acceptance model: four longitudinal field studies. Management Science 46(2):186-204.https://doi.org/10.1287/ mnsc.46.2.186.11926.

Weerasinghe S, Menaka CBH. 2018. Technology acceptance modeland social network sites (SNS): a selected review of literature. Global Knowledge, Memory and Communication 67 (3):142-153. https://doi.org/10.1108/GKMC09-2017-0079. 